\title{
Oocyte maturation with royal jelly increases embryo development and reduces apoptosis in goats
}

\author{
Arash Veshkini ${ }^{1}$, Abdollah Mohammadi-Sangcheshmeh ${ }^{2,8}$, Nasser Ghanem $^{3}$, Amir Hossein Abazari-kia $^{1}$, \\ Elmira Mottaghi ${ }^{4}$, Reza Kamaledini ${ }^{4}$, Hamid Deldar ${ }^{5}$, Irfan Ozturk ${ }^{6}$, Eduardo Leite Gastal ${ }^{7}$ \\ ${ }^{1}$ Department of Transgenic Animal Science, Stem Cell Technology Research Center, Tehran, Iran. \\ ${ }^{2}$ Department of Animal and Poultry Science, College of Aburaihan, University of Tehran, Pakdasht, Tehran, Iran. \\ ${ }^{3}$ Department of Animal Production, Faculty of Agriculture, Cairo University, Giza, Egypt. \\ ${ }^{4}$ Department of Animal Science and Technology, Faculty of Agriculture and Natural Resources, Tehran Science and Research \\ Branch, Islamic Azad University, Tehran, Iran. \\ ${ }^{5}$ Department of Animal Science, College of Animal Science and Fisheries, Sari Agricultural Sciences and Natural Resources \\ University, Sari, Iran. \\ ${ }^{6}$ Department of Biometry Science, Faculty of Agriculture, Harran University, Sanliurfa, Turkey. \\ ${ }^{7}$ Department of Animal Science, Food and Nutrition, Southern Illinois University, Carbondale, IL, USA.
}

\begin{abstract}
Royal jelly (RJ) was supplemented to goat oocyte in vitro maturation (IVM) medium at three different concentrations (2.5, 5, and $10 \mathrm{mg} / \mathrm{ml}$ ). Maturation rate, embryo cleavage, and blastocyst rate were recorded. Gene expression of apoptosis-related transcripts was investigated in matured oocytes. Percentage of oocytes that reached MII-stage was increased in RJ-treated groups compared to the control group. Glutathione (GSH) content of mature oocytes was enhanced when RJ was added to IVM medium at any supplementation compared with control. Percentage of cleaved embryos and blastocysts was higher in the RJ-treated groups at a concentration of $5 \mathrm{mg} / \mathrm{ml}$ than in the $2.5 \mathrm{mg} / \mathrm{ml}$ and control group. Total number of cells per blastocyst was not different in the control and RJtreated group at $5 \mathrm{mg} / \mathrm{ml}$. However, number of apoptotic cells per blastocyst was higher in the control group than in the RJ-treated group at $5 \mathrm{mg} / \mathrm{ml}$. Expression profile of $B a x$, and $p 53$ was down-regulated while $B c l-2$ was upregulated in oocytes treated with RJ at 5 and $10 \mathrm{mg} / \mathrm{ml}$ compared with the control group. Addition of RJ at concentrations of $5 \mathrm{mg} / \mathrm{ml}$ improved embryo production through increasing maturation rate. RJ seems to improve the IVM microenvironment by reducing expression of genes inducing apoptosis, enhancing GSH content, and reducing incidence of apoptosis in blastocysts.
\end{abstract}

Keywords: embryo, gene expression, in vitro fertilization, oocyte, royal jelly.

\section{Introduction}

The efficiency of assisted reproductive technologies (ARTs) like in vitro embryo production, intracytoplasmic sperm injection (ICSI), and somatic cell nuclear transfer (SCNT) is completely dependent on the production of higher numbers of transferable embryos of good quality. Indeed, in vitro maturation (IVM) of cumulus-oocytes complexes (COCs) is a key step in improving the outcome of ARTs. Wellestablished culture systems used for IVM have substantially influenced the maturation rate, in vitro fertilization (IVF) rate, and subsequent embryonic development rate (Brackett and Zuelke, 1993; Cox and Alfaro, 2007; Combelles et al., 2009; Souza-Fabjan et al., 2014; Fakruzzaman et al., 2015). Under in vivo conditions, COCs are provided with all essential minerals, growth factors, proteins, and natural buffering agents that cannot be mimicked totally under in vitro counterparts. However, developmental capabilities of COCs can be improved by supplementation of various hormones, growth factors, serum, cells, follicular fluid, and other substances added to the maturation media (Romero-Arredondo and Seidel, 1996; Choi et al., 2001; Zhou et al., 2016; Soto-Heras et al., 2018). In this context, the blastocyst rate was improved, reaching up to $70 \%$ when COCs were matured in vivo, while this rate dropped to $30-35 \%$ under IVM conditions (Wrenzycki and Stinshoff, 2013).

Substantial enhancement of early embryonic development has been reported (Albuz et al., 2010) when the IVM system was improved in different mammalian species. For example, the blastocyst development rate was increased in mice $(86 \%)$ and cattle (69\%) by applying simulated physiologic oocyte maturation. Furthermore, the implantation rate $(53 \%)$ and fetal yield $(26 \%)$ were also improved in mice (Albuz et al., 2010). From a practical point of view, improving IVM conditions holds much promise in cattle and human ARTs (Edward, 2007). Although many factors have shown substantial contribution to in vitro embryo production (IVEP), maintenance of adequate balance between production and scavenging of oxidative stress is of great importance (Guerin et al., 2001). Generally, COCs are negatively affected by increased oxidative stress during IVM due to higher reactive oxygen species (ROS) than that under an in vivo environment. Under in vivo conditions, oocytes and embryos are able to resist oxidative stress by antioxidants, which are present in follicular fluid (Oyawoye et al., 2003) or produced by embryos themselves in the oviduct (Gardiner and Reed, 1995). In this regard, royal jelly has been described as an effective antioxidant (Bărnuţiu et al., 2011). Royal jelly is a viscous secretion of both hypopharyngeal and mandibular glands of young worker bees that is used to 
feed the queen honeybee throughout the larval period (Viuda-Martos et al., 2008; Isidorova et al., 2009). It contains the following: water $(50-60 \%)$, proteins $(18 \%)$, carbohydrates $(15 \%)$, lipids (3-6\%), mineral salts $(1.5 \%)$, and vitamins, in addition to various bioactive substances (Howe et al., 1985; Boselli et al., 2003; Nagai and Inoue 2004; Kodai et al., 2007; Tamura et $a l ., 2009)$. The antioxidative capacity of royal jelly was shown to be effective in protecting female and male gametes (Guo et al., 2009) and cryopreserved semen (Moradi et al., 2013; Shahzad et al., 2016).

The current study is the first to test if the supplementation of royal jelly as an antioxidant agent during IVM culture of goat COCs could be beneficial. After culture, nuclear maturation, glutathione content, preimplantation development, and the expression profile of apoptosis-related transcripts were examined.

\section{Materials and Methods}

\section{Chemicals and media}

Unless otherwise mentioned, all the chemicals, reagents, media, and constituents used for media preparation were purchased from Sigma-Aldrich Chemicals, USA. Capsulated pure royal jelly was provided by Natural Life ${ }^{\mathrm{TM}}$ (Brookvale, NSW, Australia). According to manufacturer's reports, the chemical composition was water $1.6 \%(\mathrm{w} / \mathrm{w})$, proteins $40.1 \%(\mathrm{w} / \mathrm{w})$, carbohydrates $47.3 \%(\mathrm{w} / \mathrm{w})$, lipids $7.9 \%$ $(\mathrm{w} / \mathrm{w})$, ashes $3.1 \%(\mathrm{w} / \mathrm{w})$, sodium $36.3 \mathrm{mg} / 100 \mathrm{~g}$, phosphorus $672 \mathrm{mg} / 100 \mathrm{~g}$, calcium $19.5 \mathrm{mg} / 100 \mathrm{~g}$, magnesium $90.9 \mathrm{mg} / 100 \mathrm{~g}$, zinc $6.8 \mathrm{mg} / 100 \mathrm{~g}$, iron $3.0 \mathrm{mg} / 100 \mathrm{~g}$, and free amino acids $1583 \mathrm{mg} / 100 \mathrm{~g}$.

\section{COC collection and IVM}

Goat ovaries were collected from a local slaughterhouse and transported in physiological saline containing antibiotics $(100 \mathrm{IU} / \mathrm{ml}$ penicillin and $100 \mathrm{mg} / \mathrm{ml}$ streptomycin) at $35^{\circ} \mathrm{C}$ to the lab within 2-3 h. COCs were collected by slicing the ovaries in HEPES-buffered synthetic oviductal fluid (HSOF). The COCs were morphologically selected based on the number of cumulus cell layers and cytoplasm homogeneity (Mohammadi-Sangcheshmeh et al., 2012). The collected COCs were washed three times in maturation medium (TCM-199 supplemented with $2 \mathrm{mM}$ l-glutamine, $10 \%$ fetal bovine serum, $5.5 \mathrm{mg} / \mathrm{ml}$ sodium pyruvate, $25 \mu \mathrm{g} / \mathrm{ml}$ gentamycin sulphate, $5.0 \mu \mathrm{g} / \mathrm{ml} \mathrm{LH}$, $0.5 \mu \mathrm{g} / \mathrm{ml} \mathrm{FSH}$, and $1 \mu \mathrm{g} / \mathrm{ml}$ estradiol). IVM was performed in $50 \mu \mathrm{l}$ maturation medium droplets under mineral oil for $24 \mathrm{~h}$ at $39^{\circ} \mathrm{C}$ and $5 \% \mathrm{CO}_{2}$ in air.

\section{Evaluation of cumulus expansion}

COCs from all treatment groups were evaluated at the end of IVM to assess cumulus cell expansion. Briefly, cumulus expansion was evaluated by a subjective scoring system (Lorenzo et al., 1994), which considered no detectable response set as (0) value and highest degree of expansion as $(+++)$.

\section{Nuclear chromatin evaluation}

For nuclear maturation assessment, cumulus cells were removed from COCs by pipetting in presence of hyaluronidase $(200 \mathrm{U} / \mathrm{ml})$. Denuded oocytes were fixed in $4 \%(\mathrm{v} / \mathrm{v})$ paraformaldehyde in PBS. Oocytes were stained with $2.5 \mathrm{mg} / \mathrm{ml}$ Hoechst 33258 in $3: 1(\mathrm{v} / \mathrm{v})$ glycerol/PBS. Oocytes were then evaluated in relation to their meiotic stage and classified as germinal vesicle (GV); metaphase I (MI), including metaphase I, anaphase I, and telophase I; metaphase II (MII); and degenerated.

\section{Measurement of intracellular GSH content}

Mature COCs were denuded directly after IVM and incubated in Tyrode's medium plus $5 \mathrm{mg} / \mathrm{ml}$ polyvinyl alcohol containing $10 \mathrm{mM}$ 4-chloromethyl-6,8difluoro-7-hydroxycoumarin (Cell tracker blue; $\mathrm{CMF}_{2} \mathrm{HC}$; Invitrogen Corporation, Carlsbad, CA, USA) for $30 \mathrm{~min}$ (Abazari-Kia et al., 2015). After staining, oocytes were washed three times in mPBS, placed into 10 $\mu \mathrm{l}$ droplets, observed under an epifluorescence microscope (Nikon, Tokyo, Japan) with UV filters, and then all fluorescent images were recorded as graphic files. The fluorescence intensity of each mature oocyte was analyzed by ImageJ software (http://rsb.info.nih.gov/ij).

\section{IVF and embryo culture}

Following IVM and cumulus expansion evaluation, COCs were washed twice in HSOF and once in IVF medium [SOF supplemented with $4 \mathrm{IU} / \mathrm{ml}$ heparin, PHE $(20 \mathrm{mM}$ penicillamine, $10 \mathrm{mM}$ hypotaurine, $1 \mathrm{mM}$ epinephrine), and $2 \%(\mathrm{v} / \mathrm{v})$ sheep serum], then placed in $50 \mu \mathrm{l}$ drops of IVF medium overlaid with mineral oil. Frozen semen from a goat buck that had been evaluated before for IVEP was used for IVF. A single straw of frozen semen was thawed at $37^{\circ} \mathrm{C}$ for $30 \mathrm{sec}$ and sperms were washed at $500 \mathrm{~g}$ for $10 \mathrm{~min}$, twice with Sperm Tyrode's Albumin Lactate Pyruvate medium (Sperm-TALP) containing $10 \mu \mathrm{g} / \mathrm{ml}$ heparin, $2.2 \mathrm{mg} / \mathrm{ml}$ sodium pyruvate and bovine serum albumin (BSA) F-V $(6 \mathrm{mg} / \mathrm{ml})+50 \mu \mathrm{g} / \mathrm{ml}$ gentamycin. After washing, a sperm pellet was suspended in $0.5 \mathrm{ml}$ of fresh Fert-TALP medium supplemented with $6 \mathrm{mg} / \mathrm{ml}$ BSA (fatty acid free) $+10 \mu \mathrm{g} / \mathrm{ml}$ heparin $+3 \mu \mathrm{l} \mathrm{PHE}$ and $50 \mu \mathrm{g} / \mathrm{ml}$ gentamycin. Sperm concentration was adjusted to $2 \times 10^{6}$ spermatozoa $/ \mathrm{ml}$. The washed suspended sperms were incubated with mature COCs for $18 \mathrm{~h}$ under $5 \% \mathrm{CO} 2$ in humidified air at $39^{\circ} \mathrm{C}$.

The fertilized COCs were denuded by repeat pipetting and thoroughly washed three times in HSOF. The presumptive zygotes were washed in SOFaa $(2 \%$ BM Essential amino acids, 1\% MEM-nonessential amino acids) and supplemented with $8 \mathrm{mg} / \mathrm{ml}$ bovine serum albumin, $1 \mathrm{mM}$ glutamine, $0.34 \mathrm{mM}$ tri-sodium citrate, and $2.77 \mathrm{mM}$ myoinositol. The presumptive zygotes were cultured in groups of 15 to 20 in $50 \mu \mathrm{l}$ droplets of the culture medium (SOFaa) and covered with mineral oil at $39^{\circ} \mathrm{C}$ under $5 \% \mathrm{CO} 2$ in humidified air until day 8 . The stage of embryonic development was evaluated at day 3 and 8 post-fertilization, and the medium replacement was performed every $48 \mathrm{~h}$. 


\section{Total cell count and number of apoptotic cells assay}

The terminal deoxynucleotidyl transferase dUTP nick end labeling (TUNEL) assay was performed using an In Situ Cell Death Detection Kit according to the manufacturer's instructions (Fluorescein; Roche Diagnostics Corp., Indianapolis, USA). Day 8 blastocysts from the control and $5 \mathrm{mg} / \mathrm{ml}$ royal jellytreated groups were washed twice in PBS $\left(\mathrm{Ca}^{2+}\right.$ and $\mathrm{Mg}^{2+}$ free) supplemented with $0.2 \%$ polyvinylpyrrolidone (PBS-PVP). Embryos were then fixed in $4 \%$ paraformaldehyde in PBS-PVP and kept at $4{ }^{\circ} \mathrm{C}$ until assay was done. Fixed embryos were first washed twice in PBS-PVP then treated with $0.3 \%$ Triton $\mathrm{X}$ 100 in PBS-PVP for $30 \mathrm{~min}$ at $37^{\circ} \mathrm{C}$ for permeabilization. Embryos were washed twice in PVPPBS and incubated in the dark with TUNEL reaction mixture for $1 \mathrm{~h}$ at $37^{\circ} \mathrm{C}$. Subsequently, embryos were washed three times in PBS-PVP for $10 \mathrm{~min}$ each and stained with Hoechst $33342(10 \mu \mathrm{g} / \mathrm{ml})$. After staining, embryos were placed onto a glass slide and examined using an epifluorescence microscope (Nikon, Tokyo, Japan).

\section{RNA isolation}

Total RNA was extracted using PicoPure ${ }^{\mathrm{TM}}$ RNA isolation kit (MDS Analytical Technologies $\mathrm{GmbH}$, Ismaning, Germany) according to manufacturer's instructions. Mature oocytes from each group were incubated in $100 \mu \mathrm{l}$ extraction buffer at $42^{\circ} \mathrm{C}$ for $30 \mathrm{~min}$ to release RNA. The lysis of each group was loaded onto a pre-conditioned purification column and centrifuged to allow for the RNA to bind to the spin column. In-column DNA digestion was carried out using RNase-free DNase (Qiagen GmbH, Hilden, Germany). The column was washed twice with washing buffer and finally eluted with $12 \mu \mathrm{l}$ RNase free water. Nanodrop 1000 Spectrophotometer (Thermo Fisher
Scientific) was used to measure RNA concentration and evaluate the quality.

The synthesis of cDNA from all samples was performed using reverse transcription kit (Invitrogen, Karlsruhe, Germany). In addition, $1 \mu$ oligo dT23 $(2.5 \mu \mathrm{M})$ primer and $1 \mu \mathrm{l}$ random hexamer primer $(60 \mu \mathrm{m})$ were added to a $10 \mu \mathrm{lmRNA}$ sample and the mixture was incubated for $3 \mathrm{~min}$ at $70^{\circ} \mathrm{C}$ and cooled on ice. Eight microliters of the master mix containing $4 \mu \mathrm{l}$ of $5 \mathrm{x}$ first strand buffer, $2 \mu \mathrm{l}$ of $0.1 \mathrm{M}$ DTT, $1 \mu \mathrm{l}$ of dNTP $(10 \mathrm{pmol} / \mu \mathrm{l})$, and $0.3 \mu \mathrm{l}$ of RNase inhibitor and $0.7 \mu \mathrm{l}$ of SuperScript IITM reverse transcriptase (200 unit/ $\mu \mathrm{l}$ ) was added to the mixture and incubated for $90 \mathrm{~min}$ at $42^{\circ} \mathrm{C}$, followed by heat inactivation for $15 \mathrm{~min}$ at $70^{\circ} \mathrm{C}$. The synthesized cDNA was stored at $-20^{\circ} \mathrm{C}$ for further use.

\section{Quantitative real-time PCR analysis}

Primers used for quantitative Real-time PCR were designed using Primer3 Express version 4.0.0 software (http://primer3.wi.mit.edu//) based on the gene sequences available in NCBI GenBank (Table 1). Bovine YWHAZ gene was used as an endogenous control, and run in separate wells using ABI PRISM ${ }^{\circledR}$ 7000 instrument (Applied Biosystems). All PCR runs were done in a total volume of $20 \mu \mathrm{l}$ containing $10 \mu \mathrm{l}$ of $2.5 \mathrm{X}$ RealMasterMix/20x SYBR (Eppendorf, Hamburg, Germany). Samples were run in duplicate to maximize accuracy of real-time results. The thermal cycling was set as $10 \mathrm{sec}$ at $50^{\circ} \mathrm{C}, 10 \mathrm{~min}$ at $95^{\circ} \mathrm{C}, 45$ cycles of $15 \mathrm{sec}$ at $95^{\circ} \mathrm{C}$ and $60 \mathrm{sec}$ at $60^{\circ} \mathrm{C}$. The dissociation curve was generated by starting the fluorescence acquisition at $60^{\circ} \mathrm{C}$ and taking measurements every $7 \mathrm{sec}$ until the temperature reached $95^{\circ} \mathrm{C}$. Gene expression analysis was performed using $\Delta \Delta \mathrm{C}(\mathrm{t})$ method after normalization of the transcript abundance of each target gene relative to that of the YWHAZ.

Table 1. Details of primers used for real-time PCR quantitative analysis.

\begin{tabular}{|c|c|c|c|c|}
\hline $\begin{array}{l}\text { Gene } \\
\text { name }\end{array}$ & $\begin{array}{l}\text { GenBank accession } \\
\text { number }\end{array}$ & $\begin{array}{l}\text { Primer } \\
\text { sequences }\end{array}$ & $\begin{array}{l}\text { Annealing } \\
\text { temperature }\left({ }^{\circ} \mathrm{C}\right)\end{array}$ & $\begin{array}{l}\text { Product } \\
\text { size (bp) }\end{array}$ \\
\hline Bax & NM_173894.1 & $\begin{array}{l}\text { F:5'-GCATCCACCAAGAAGCTGAG-3' } \\
\text { R:5'-CCGCCACTCGGAAAAAGAC-3' }\end{array}$ & 61 & 130 \\
\hline$B c l-2$ & NM_001166486.1 & $\begin{array}{l}\text { F:5'-ATGTGTGTGGAGAGCGTCA-3' } \\
\text { R:5'-AGAGACAGCCAGGAGAAATC-3' }\end{array}$ & 60 & 182 \\
\hline$p 53$ & NM_174201.2 & $\begin{array}{l}\text { F:5'-AGGGGAAAGCAGGGCTCACTCT-3' } \\
\text { R:5'-GGGATATGGGTGGGGATGTCAA-3' }\end{array}$ & 60 & 151 \\
\hline$Y W H A Z$ & NM_174814.2 & $\begin{array}{l}\text { F:5'-GAAGAGTCCTACAAAGACAGCACGC-3' } \\
\text { R:5'-AATTTTCСССТССТTСТССТGC-3' }\end{array}$ & 60 & 115 \\
\hline
\end{tabular}

$\mathrm{F}$, forward; PCR, polymerase chain reaction; $\mathrm{R}$, reverse. 


\section{Statistical analyses}

The data of gene expression profile was analyzed using General Linear Model (GLM) of the Statistical Analysis System (SAS) software program 8.0 (SAS Institute Inc., NC, USA). Mean values were considered significant at $\mathrm{P}<0.05$ and after tested using ANOVA followed by a multiple pair wise comparison of t-test.

\section{Experimental design}

Cumulus-oocyte complexes recovered from slaughterhouse ovaries were allocated into three groups during IVM in presence of RJ with three different concentrations $(2.5,5$, and $10 \mathrm{mg} / \mathrm{ml})$. Following IVM, cumulus expansion score and nuclear maturation rate were checked to evaluate the effect of treatment on IVM. The presumed zygotes were then cultured without any supplementation to follow up embryo development until blastocyst formation at day 8 . Based on the result of nuclear maturation and blastocyst rates, RJ concentration of $5 \mathrm{mg} / \mathrm{ml}$ was selected for investigating embryo quality (total cell number and apoptotic cell number). The beneficial effect of RJ supplementation on goat COCs during IVM was further studied at cytoplasmic and molecular levels. Therefore, GSH content was measured in all treatment groups. In addition, gene expression profile of apoptosis-related transcripts was performed using quantitative real-time PCR.

\section{Results}

\section{Cumulus expansion}

The data of COCs that attained expansion is shown (Fig. 1). No difference in cumulus expansion score was detected among the different royal jellytreated groups and the control. Although not significant $(\mathrm{P}>0.05)$, the percentage of fully expanded COCs increased when royal jelly was supplemented to IVM medium at a concentration of $5 \mathrm{mg} / \mathrm{ml} \mathrm{(54.7 \% )}$ compared with $2.5 \mathrm{mg} / \mathrm{ml}$ (49.4\%), $10 \mathrm{mg} / \mathrm{ml} \mathrm{(45.8 \% ),}$ and control (47.3\%) groups.

\section{Nuclear maturation}

The percentage of oocytes that reached MIIstage increased $(\mathrm{P}<0.05)$ steadily with increasing concentrations of royal jelly during IVM groups (Table 2). In addition, the percentage of MII-stage oocytes was higher at $10 \mathrm{mg} / \mathrm{ml}(88.0 \% \pm 1.7), 5 \mathrm{mg} / \mathrm{ml}$ $(80.9 \% \pm 0.6)$, and $2.5 \mathrm{mg} / \mathrm{ml}(71.4 \% \pm 2.3)$ than in the control $(60.0 \% \pm 1.7)$ group.

\section{Glutathione content}

Glutathione content measured by fluorescent intensity of mature oocytes was enhanced $(\mathrm{P}<0.05)$ when royal jelly was supplemented to IVM medium at $10 \mathrm{mg} / \mathrm{ml}$ (293.4 arbitrary units), $5 \mathrm{mg} / \mathrm{ml}$ (286.5 arbitrary units), and $2.5 \mathrm{mg} / \mathrm{ml}$ (272.8 arbitrary units) compared with the control (210.6 arbitrary units) group (Fig. 2 and 3).

\section{Early development and blastocyst rate}

The rate of cleaved and day 8 embryos was higher $(\mathrm{P}<0.05)$ in the royal jelly-treated groups at a concentration of $5 \mathrm{mg} / \mathrm{ml}(70.2 \% \pm 3.2$ and $33.1 \% \pm 2.2)$ than in $2.5 \mathrm{mg} / \mathrm{ml}(59.2 \% \pm 3.3$ and $21.2 \% \pm 4.1)$ and the control groups $(54.5 \% \pm 3.6$ and $22.3 \% \pm 3.7)$. Compared to other experimental groups, no significant $(\mathrm{P}<0.05)$ improvement was observed in the percentage of cleaved embryos $(69.8 \% \pm 2.1)$ and day 8 blastocysts $(26.4 \% \pm 3.5)$ when royal jelly was added at a concentration of $10 \mathrm{mg} / \mathrm{ml}$ (Table 3 ).

Total number of cells and the number of apoptotic cells per blastocyst

Blastocyst cell count was similar $(\mathrm{P}<0.05)$ in the control $(114.7 \pm 8.0)$ and treated groups at a concentration of $5 \mathrm{mg} / \mathrm{ml}(117.5 \pm 9.6$; Table 4). However, the number of apoptotic cells was higher $(\mathrm{P}<0.05)$ in the control $(7.9 \pm 2.2)$ than in the treated group $(4.1 \pm 1.4)$

\section{Gene expression profile}

The expression profile of apoptotic-induced (Bax and p53) and an anti-apoptotic (Bcl-2) gene were performed in oocytes after IVM in the presence or absence of royal jelly (Fig. 4). Both genes involved in apoptosis induction (Bax and p53) were expressed more highly $(\mathrm{P}<0.05)$ in control oocytes compared to the royal jelly-treated ones at concentrations of 5 and $10 \mathrm{mg} / \mathrm{ml}$. However, when royal jelly was added to IVM medium at $2.5 \mathrm{mg} / \mathrm{ml}$, the expression profile of $p 53$ was not different $(\mathrm{P}>0.05)$ from either the control or other treatment groups. On the other hand, expression of anti-apoptotic $\mathrm{Bcl}-2$ transcript was increased significantly in all oocytes treated with royal jelly at concentrations of 5 and $10 \mathrm{mg} / \mathrm{ml}$, while at $2.5 \mathrm{mg} / \mathrm{ml}$ it was expressed in treated oocytes similarly to all other experimental groups (Fig. 4). 


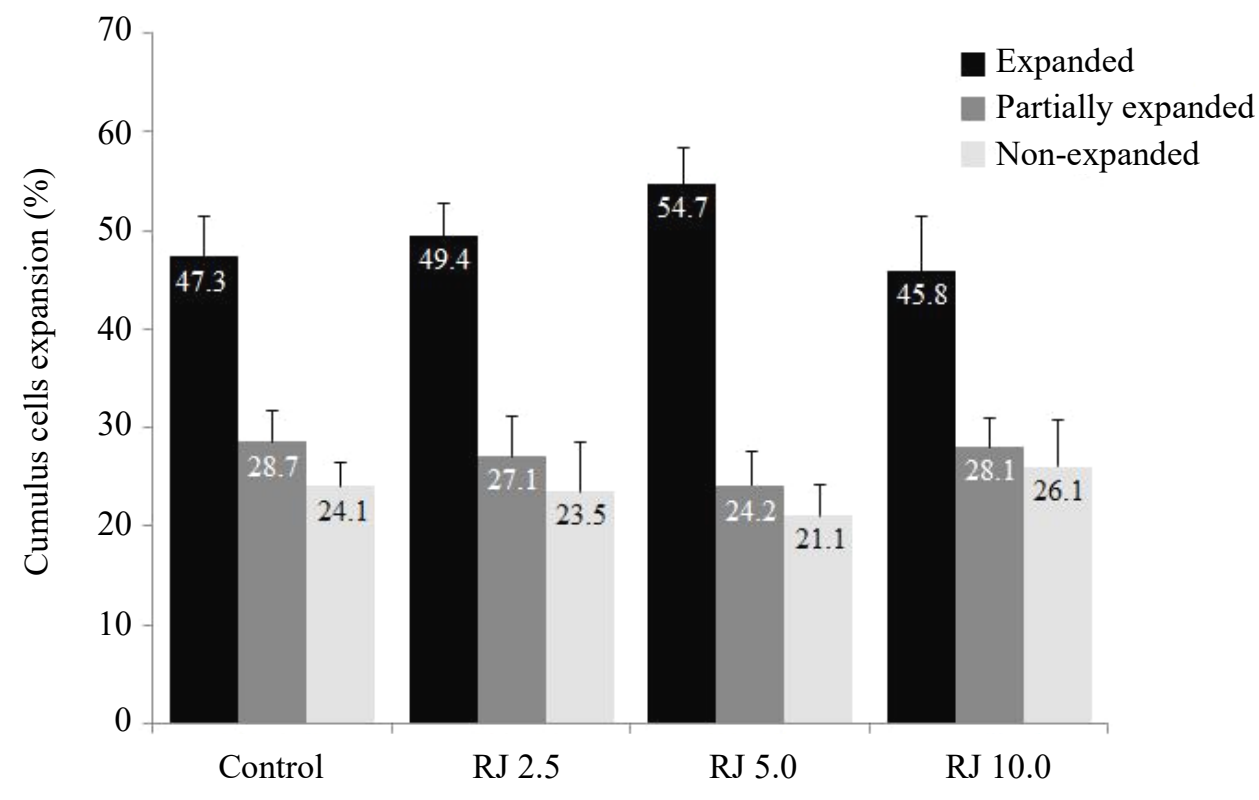

Figure 1. Percentages of cumulus expansion score (fully expanded, partially expanded, and non-expanded) of COCs treated with different concentrations of royal jelly during IVM. ${ }^{\text {a,b,c,d }}$ Bars with uncommon superscripts are different $(\mathrm{P}<0.05)$.

Table 2. Nuclear status of goat oocytes treated with different concentrations of royal jelly after $24 \mathrm{~h}$ of in vitro maturation (cumulative results of five replicates).

\begin{tabular}{lcrccc}
\hline & & \multicolumn{3}{c}{ Nuclear status (mean \pm SEM) } \\
\cline { 2 - 5 } Group & Oocytes $(\mathrm{n})$ & GV $(\%)$ & GVBD $(\%)$ & MI (\%) & MII (\%) \\
\hline Control & 110 & $14.5 \pm 0.6^{\mathrm{a}}$ & $10.9 \pm 0.0^{\mathrm{a}}$ & $14.5 \pm 1.1^{\mathrm{a}}$ & $60.0 \pm 1.7^{\mathrm{c}}$ \\
RJ 2.5 & 168 & $5.9 \pm 0.3^{\mathrm{b}}$ & $8.3 \pm 0.6^{\mathrm{ab}}$ & $14.3 \pm 0.6^{\mathrm{ab}}$ & $71.4 \pm 2.3^{\mathrm{b}}$ \\
RJ 5.0 & 126 & $3.2 \pm 0.6^{\mathrm{c}}$ & $6.3 \pm 0.3^{\mathrm{ab}}$ & $9.5 \pm 0.0^{\mathrm{b}}$ & $80.9 \pm 0.6^{\mathrm{ab}}$ \\
RJ 10.0 & 134 & $1.5 \pm 0.0^{\mathrm{c}}$ & $3.0 \pm 0.6^{\mathrm{b}}$ & $7.5 \pm 1.1^{\mathrm{b}}$ & $88.0 \pm 1.7^{\mathrm{a}}$ \\
\hline
\end{tabular}

RJ 2.5: Control maturation medium supplemented with $2.5 \mathrm{mg} / \mathrm{ml}$ royal jelly; RJ 5.0: Control maturation medium supplemented with $5.0 \mathrm{mg} / \mathrm{ml}$ royal jelly; RJ 10.0: Control maturation medium supplemented with $10.0 \mathrm{mg} / \mathrm{ml} \mathrm{royal}$ jelly; GV: Germinal vesicle; GVBD: Germinal vesicle break down; MI: Metaphase I; MII: Metaphase II. ${ }^{\text {a,b,c }}$ Within columns, values with uncommon superscripts differ $(\mathrm{P}<0.05)$.

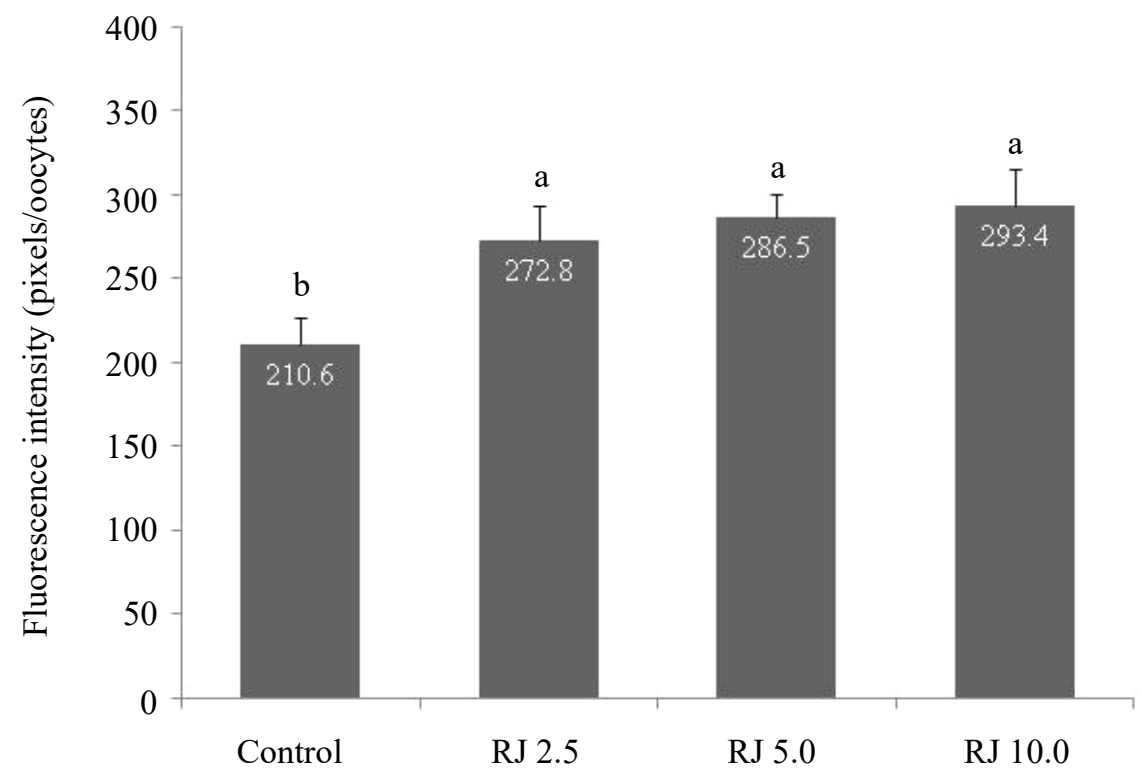

Figure 2. Glutathione content of oocytes treated with different concentrations of royal jelly during IVM. ${ }^{\mathrm{a}, \mathrm{b}, \mathrm{c}, \mathrm{d}}$ Bars with uncommon superscripts are different $(\mathrm{P}<0.05)$. 

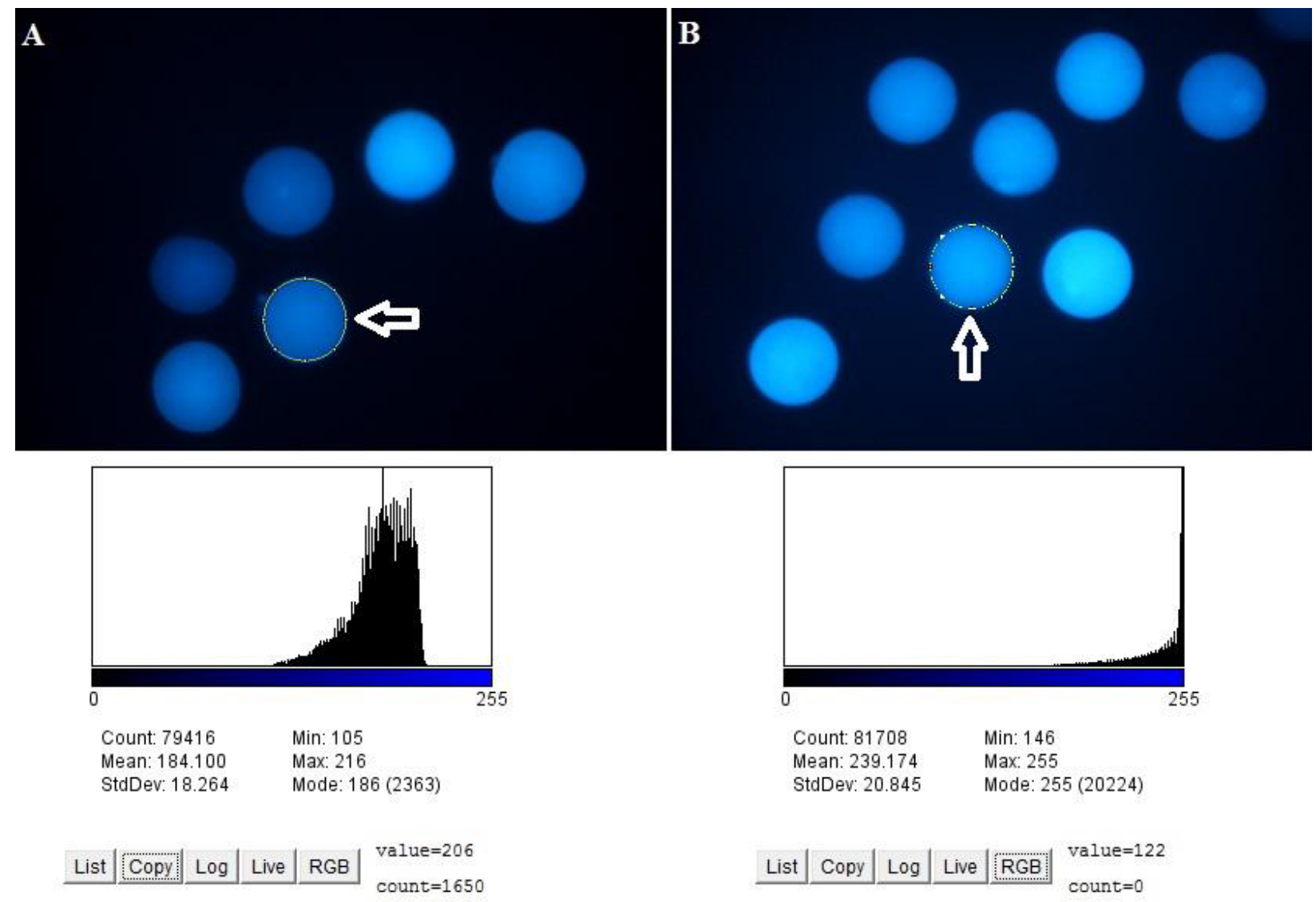

Figure 3. Representative images of oocytes' fluorescent intensity for glutathione content.

Table 3. Embryo development of royal jelly-treated and control oocytes at 8 days after in vitro fertilization (IVF) in goats (cumulative results of five replicates).

Embryo development (mean \pm SEM)

\begin{tabular}{lccc} 
Groups & Oocytes (n) & Cleaved (\%) & Blastocyst (\%) \\
\hline Control & 112 & $54.5 \pm 3.6^{\mathrm{b}}$ & $22.3 \pm 3.7^{\mathrm{b}}$ \\
RJ 2.5 & 121 & $59.2 \pm 3.3^{\mathrm{b}}$ & $21.2 \pm 4.1^{\mathrm{b}}$ \\
RJ 5.0 & 118 & $70.2 \pm 3.2^{\mathrm{a}}$ & $33.1 \pm 2.2^{\mathrm{a}}$ \\
RJ 10.0 & 107 & $69.8 \pm 2.1^{\mathrm{a}}$ & $26.4 \pm 3.5^{\mathrm{ab}}$ \\
\hline
\end{tabular}

RJ 2.5: Control maturation medium supplemented with $2.5 \mathrm{mg} / \mathrm{ml}$ royal jelly; RJ 5.0: Control maturation medium supplemented with $5.0 \mathrm{mg} / \mathrm{ml}$ royal jelly; RJ 10.0: Control maturation medium supplemented with $10.0 \mathrm{mg} / \mathrm{ml} \mathrm{royal}$ jelly. ${ }^{a, b}$ Within columns, values with uncommon superscripts differ $(\mathrm{P}<0.05)$.

Table 4. Total cell number and apoptotic cell number in blastocysts derived from royal jelly-treated and control oocytes.

\begin{tabular}{lccc} 
& & \multicolumn{2}{c}{ Embryo quality (mean \pm SEM) } \\
\cline { 3 - 4 } Groups & Blastocysts (n) & Blastocyst nuclei (n) & Apoptotic cells (n) \\
\hline Control & 23 & $114.7 \pm 8.0$ & $7.9 \pm 2.2^{\mathrm{a}}$ \\
RJ 5.0 & 26 & $117.5 \pm 9.6$ & $4.1 \pm 1.4^{\mathrm{b}}$ \\
\hline
\end{tabular}

RJ 5.0: Control maturation medium supplemented with $5.0 \mathrm{mg} / \mathrm{mL}$ royal jelly. ${ }^{\mathrm{a}, \mathrm{b}}$ Within columns, values with uncommon superscripts differ $(\mathrm{P}<0.05)$. 

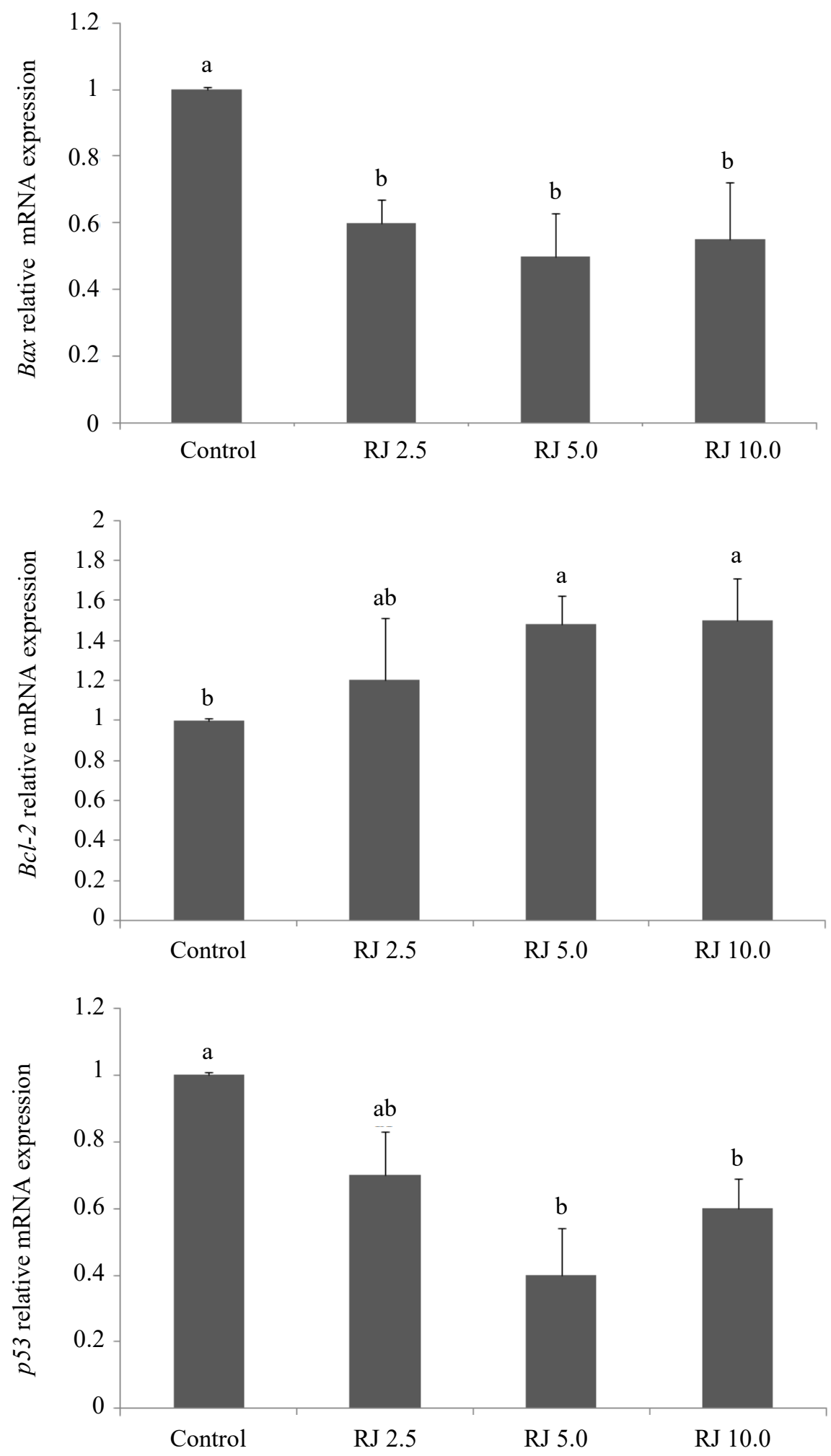

Figure 4. Expression profile of $B a x, B c l-2$, and $p 53$ genes in oocytes treated with different concentrations of royal jelly during IVM using quantitative real-time PCR. ${ }^{\text {a,b,c,d }}$ Bars with uncommon superscripts are different $(P<0.05)$.

\section{Discussion}

The oocyte microenvironment is a key determinant factor in IVEP success (Greve et al., 1987; Rizos et al., 2002; Sutton et al., 2003). There are different ways to improve the oocyte microenvironment during the course of the maturation process. Co-culture of intact
COCs with a specific ratio of denuded oocytes has improved nuclear, cytoplasmic maturation (Dey et al., 2012; Souza-Fabjan et al., 2016) and the rate of blastocyst formation, in addition to quality (Choi et al., 2013). Antioxidants such as peroxiredoxin II (Fakruzzaman et al., 2015), melatonin (Do et al., 2015), resveratrol (Kwak et al., 2012), l-carnitine 
(Mishra et al., 2016), cysteine (Ali et al., 2003), and cysteamine (Rodríguez-González et al., 2003) have been supplemented to IVM media to improve developmental competence of pre-implantation blastocysts of different mammalian species. In our study, supplementation of royal jelly to IVM medium has increased the rate at which oocytes reached MIIstage in a dose-dependent manner, although the cumulus expansion was not different from that of the control group. In agreement with our results, Valiollahpoor et al. (2016) has reported higher maturation rates of sheep oocytes when cultured in the presence of royal jelly at various concentrations. The positive effect of royal jelly in improving COC maturation could be due to the various active compounds like proteins, essential amino acids (cystine, lysine and arginine), sugars (fructose, glucose, and sucrose), vitamins (A, B5, C, D and E), and lipids (Howe et al., 1985; Boselli et al., 2003; Kodai et al., 2007; Tamura et al., 2009). An early study observed increased errors in chromosomal segregation due to high oxidative stress during IVM, which compromises oocyte developmental potential after IVF in mice (Tarin et al., 1996).

Intracellular content of GSH is one of the crucial indicators of the developmental capacity of COCs. Highly developmental competent goat $\mathrm{BCB}+$ oocytes have previously been shown to increase the intracellular GSH content compared with BCB- (with low developmental competence) and control oocytes (Abazari-Kia et al., 2014). The results of the present study indicated enhancement of oocytes glutathione content linearly with increasing concentrations of royal jelly supplemented to IVM medium, which subsequently increased maturation rate. The content of GSH and ATP concentrations has been analyzed in in vitro- and in vivo-matured porcine COCs (Brad et al., 2003). Porcine oocytes matured in vivo had a significantly higher content of GSH and developmental competence compared with in vitro-matured counterparts (Brad et al., 2003). Lower intracellular GSH was also linked with reduced developmental potential of bovine oocytes (Hashimoto et al., 2000; Furnus et al., 2008). The enhanced effect of royal jelly on intracellular GSH content could be due to an increase in the synthesizing of GSH within COCs during IVM. In accordance with our results, supplementation of IVM media with crocin as an antioxidant substance has increased nuclear maturation rate and subsequent developmental potential of mouse oocytes, which may occur through its beneficial effect in increasing GSH concentrations in MII oocytes (Maleki et al., 2016). Similarly, IVM media supplemented with an antioxidant known as either resveratrol (Kwak et al., 2012) or carboxyethyl germanium sesquioxide (Ge-132; Kim et al., 2015) improved embryonic development after parthenogenetic activation of porcine COCs and SCNT (Jin et al., 2016) by increasing the intracellular GSH levels.

These findings also highlight a vital biological property of royal jelly as an antioxidant (Bărnuţiu et al., 2011) that protects female and male gametes (Guo et al., 2009) and cryopreserved semen (Moradi et al.,
2013; Shahzad et al., 2016). In support of the antioxidant property, expression profile of apoptosisrelated transcripts (Bax and p53) was suppressed in oocytes treated with royal jelly at 5 and $10 \mathrm{mg} / \mathrm{ml}$. Additionally, the transcript abundance of anti-apoptotic gene $(\mathrm{Bcl}-2)$ was up-regulated after supplementation of IVM medium with royal jelly of 5 and $10 \mathrm{mg} / \mathrm{ml}$. The antioxidative activity of royal jelly has been confirmed through its protection against oxidative stress when given to experimental animals (El-Nekeety et al., 2007; Silici et al., 2009). Moreover, growing rabbits administered royal jelly have improved their physiological conditions (Elnagar et al., 2010), while adult males have experienced reduced summer infertility under heat stress (Elnagar, 2010). Also, pregnancy rate and overall reproductive performance was improved in ewes administered royal jelly (Kridli et al., 2003; Husein and Haddad, 2006; Kridli and AlKhetib, 2006). Thus, results from this and previous studies confirm the beneficial antioxidative effect of royal jelly in reducing the incidence of apoptosis in oocytes during IVM, which was coupled with enhancing mitochondria activity.

The influence of royal jelly in improving oocyte maturation and quality was extended to improve the percentage of cleaved embryos and blastocyst rate in the royal jelly-treated groups at concentrations of 5 and $10 \mathrm{mg} / \mathrm{ml}$ compared to $2.5 \mathrm{mg} / \mathrm{ml}$ and the control group. The synergistic effect of royal jelly on embryo development could be attributed to improving the IVM microenvironment (Choi et al., 2013), in addition to increasing nuclear and cytoplasmic maturation of oocytes (Dey et al., 2012). Interestingly, it seems that the royal jelly antioxidative potentiality could also be sustained throughout embryo cleavage until blastocyst formation, as observed in the current study and previous reports when various antioxidant supplements were used during IVM (Ali et al., 2003; Rodríguez-González et al., 2003; Kwak et al., 2012; Do et al., 2015; Fakruzzaman et al., 2015; Mishra et al., 2016). Enhancement of bovine oocytes' glutathione content was induced by supplementation of IVM media with antioxidants (cysteamine, cysteine, and mercaptoethanol), and improved results of IVEP (de Matos et al., 1995, 1996). The induction of high GSH levels during IVM was continued to the beginning of embryo culture (de Matos and Furnus, 2000). The increased level of GSH was coupled with reducing the intracellular levels of ROS, oxidative stress-induced apoptosis, and altering the expression of oocytes' molecular markers during IVM (Kwak et al., 2012; Kim et al., 2015; Jin et al., 2016). In support to this assumption, addition of resveratrol during IVM of goat COCs has significantly reduced both intracellular ROS and expression of proapoptotic (Bax) gene while increasing GSH levels (Mukherjee et al., 2014).

Overall, improvement in oocyte quality as a result of royal jelly treatment was also reflected in reducing incidence of apoptosis in embryos. Addition of different antioxidants during IVM (Leyens et al., 2004; Fakruzzaman et al., 2015) or IVC (Ghanem et al., 2014) has reduced the number of apoptotic cells in blastocysts. 
Indeed, a higher incidence of apoptosis could result in fragmentation arrest of embryos (Yoneda et al., 2004; Favetta et al., 2007), while embryos with a greater number of cells and lower incidence of apoptosis are more likely to survive and to develop to term after transfer to recipients (Van Soom et al., 2007). Supplementation of maturation medium with $5 \mathrm{mg} / \mathrm{mL}$ royal jelly increased the rate of embryo cleavage and blastocyst formation. This increase was associated with improvement of the nuclear maturation rate and cytoplasmic maturation, as shown by enhancing glutathione content and changing the expression of oocyte key genes to support subsequent embryo development. The apoptotic process was reduced in embryos developed from COCs treated with royal jelly. Therefore, our study confirms, at gene level, the beneficial antioxidant capacity of royal jelly, which could be used as a supplement of a promising IVM medium culture to enhance both embryo development and quality.

\section{Acknowledgments}

The authors thank the members of their own laboratories for their helpful discussions. This work was supported by Iran National Science Foundation, INSF [grant number: 93024412].

\section{References}

Abazari-Kia AH, Mohammadi-Sangcheshmeh A, Dehghani-Mohammadabadi M, Jamshidi-Adegani F, Veshkini A, Zhandi M, Cinar MU, Salehi M. 2014. Intracellular glutathione content, developmental competence and expression of apoptosis-related genes associated with G6PDH-activity in goat oocyte. $J$ Assist Reprod Genet, 31:313-321.

Abazari-Kia AH, Dehghani-Mohammadabadi M, Mohammadi-Sangcheshmeh A, Zhandi M, Salehi M. 2015. Regulation of embryonic development and apoptotic-related gene expression by brain-derived neurotrophic factor in two different culture conditions in ovine. Theriogenology, 84:62-69.

Albuz F, Sasseville M, Lane M, Armstrong D, Thompson J, Gilchrist R. 2010. Simulated physiological oocyte maturation (SPOM): a novel in vitro maturation system that substantially improves embryo yield and pregnancy outcomes. Hum Reprod, 25:2999-3011.

Ali A, Bilodeau J, Sirard M. 2003. Antioxidant requirements for bovine oocytes varies during in vitro maturation, fertilization and development. Theriogenology, 59:939-949.

Bărnuţiu LI, Mărghitaş LA, Dezmirean DS, Mihai CM, Bobiş O. 2011. Chemical composition and antimicrobial activity of Royal Jelly. Review. Sci Pap Anim Sci Biotechnol, 44:67-72.

Boselli E, Caboni M, Sabatini A, Marcazzan G, Lercker G. 2003. Determination and changes of free amino acids in royal jelly during storage. Apidologie, 34:129-137.

Brackett BG, Zuelke KA. 1993. Analysis of factors involved in the in vitro production of bovine embryos. Theriogenology, 39:43-64.

Brad A, Bormann C, Swain J, Durkin R, Johnson A, Clifford A, Krisher R. 2003. Glutathione and adenosine triphosphate content of in vivo and in vitro matured porcine oocytes. Mol Reprod Dev, 64:492-498.

Choi B-H, Bang J-I, Jin J-I, Kim S-S, Jo H-T, Deb GK, Ghanem N, Cho K-W, Kong I-K. 2013. Coculturing cumulus oocyte complexes with denuded oocytes alters zona pellucida ultrastructure in in vitro matured bovine oocytes. Theriogenology, 80:11171123.

Choi YH, Love CC, Varner DD, Thompson JA, Hinrichs K. 2001. Activation of cumulus-free equine oocytes: effect of maturation medium, calcium ionophore concentration and duration of cycloheximide exposure. Reproduction, 122:177-183.

Combelles CM, Gupta S, Agarwal A. 2009. Could oxidative stress influence the in-vitro maturation of oocytes? Reprod Biomed Online, 18:864-880.

Cox JF, Alfaro V. 2007. In vitro fertilization and development of OPU derived goat and sheep oocytes. Reprod Domest Anim, 42:83-87.

de Matos DG, Furnus CC, Moses DF, Baldassarre H. 1995. Effect of cysteamine on glutathione level and developmental capacity of bovine oocyte matured in vitro. Mol Reprod Dev, 42:432-436.

de Matos DG, Furnus C, Moses D, Martinez A, Matkovic M. 1996. Stimulation of glutathione synthesis of in vitro matured bovine oocytes and its effect on embryo development and freezability. Mol Reprod Dev, 45:451-457.

de Matos DG, Furnus CC. 2000. The importance of having high glutathione (GSH) level after bovine in vitro maturation on embryo development effect of betamercaptoethanol, cysteine and cystine. Theriogenology, 53:761-771.

Dey S, Deb G, Ha A, Lee J, Bang J, Lee K, Kong I. 2012. Coculturing denuded oocytes during the in vitro maturation of bovine cumulus oocyte complexes exerts a synergistic effect on embryo development. Theriogenology, 77:1064-1077.

Do L, Shibata Y, Taniguchi M, Nii M, Nguyen T, Tanihara F, Takagi M, Otoi T. 2015. Melatonin supplementation during in vitro maturation and development supports the development of porcine embryos. Reprod Domest Anim, 50:1054-1058.

Edward R. 2007. Are minimal stimulation IVF and IVM set to replace routine IVF? Reprod Biomed Online, 14:267-270.

El-Nekeety AA, El-Kholy W, Abbas NF, Ebaid A, Amra HA, Abdel-Wahhab MA. 2007. Efficacy of royal jelly against the oxidative stress of fumonisin in rats. Toxicon, 50:256-269.

EInagar S. 2010. Royal jelly counteracts bucks'summer infertility. Anim Reprod Sci, 121:174-180.

Elnagar S, Elghalid O, Abd-Elhady A. 2010. Royal jelly: can it reduce physiological strain of growing rabbits under Egyptian summer conditions? Animal, 4:1547-1552.

Fakruzzaman M, Ghanem N, Bang J-I, Ha A-N, Lee K-L, Sohn S-H, Wang Z, Lee D-S, Kong I-K. 2015. 
Effect of peroxiredoxin II on the quality and mitochondrial activity of pre-implantation bovine embryos. Anim Reprod Sci, 159:172-183.

Favetta LA, John EJS, King WA, Betts DH. 2007. High levels of p66 shc and intracellular ROS in permanently arrested early embryos. Free Radic Biol Med, 42:1201-1210.

Furnus C, De Matos D, Picco S, García P. P, Inda A, Mattioli G, Errecalde A. 2008. Metabolic requirements associated with GSH synthesis during in vitro maturation of cattle oocytes. Anim Reprod Sci, 109:88-99.

Gardiner CS, Reed DJ. 1995. Synthesis of glutathione in the preimplantation mouse embryo. Arch Biochem Biophys, 318:30-36.

Ghanem N, Ha A-N, Fakruzzaman M, Bang J-I, Lee S-C, Kong I-K. 2014. Differential expression of selected candidate genes in bovine embryos produced in vitro and cultured with chemicals modulating lipid metabolism. Theriogenology, 82:238-250.

Greve T, Xu K, Callesen H, Hyttel P. 1987. In vivo development of in vitro fertilized bovine oocytes matured in vivo versus in vitro. $J$ In Vitro Fert Embryo Transf, 4:281-285.

Guerin P, El Mouatassim S, Menezo Y. 2001. Oxidative stress and protection against reactive oxygen species in the pre-implantation embryo and its surroundings. Hum Reprod Update, 7:175-189.

Guo H, Kouzuma Y, Yonekura M. 2009. Structures and properties of antioxidative peptides derived from royal jelly protein. Food Chem, 113:238-245.

Hashimoto S, Minami N, Yamada M, Imai H. 2000. Excessive concentration of glucose during in vitro maturation impairs the developmental competence of bovine oocytes after in vitro fertilization: relevance to intracellular reactive oxygen species and glutathione contents. Mol Reprod Dev, 56:520-526.

Howe S, Dimick P, Benton A. 1985. Composition of freshly harvested and commercial royal jelly. J Apicult Res, 24:52-61.

Husein M, Haddad S. 2006. A new approach to enhance reproductive performance in sheep using royal jelly in comparison with equine chorionic gonadotropin. Anim Reprod Sci, 93:24-33.

Isidorova VA, Czyzewskaa U, Isidorovab AG, Bakier S. 2009. Gas chromatographic and mass spectrometric characterization of the organic acids extracted from some preparations containing lyophilized royal jelly. $J$ Chromatogr B Analyt Technol Biomed Life Sc., 877:3776-3780.

Jin J, Lee S, Khoirinaya C, Oh A, Kim G, Lee B. 2016. Supplementation with spermine during in vitro maturation of porcine oocytes improves early embryonic development after parthenogenetic activation and somatic cell nuclear transfer. J Anim Sci, 94:963970.

Kim E, Jeon Y, Kim DY, Lee E, Hyun S-H. 2015. Antioxidative effect of carboxyethylgermanium sesquioxide (Ge-132) on IVM of porcine oocytes and subsequent embryonic development after parthenogenetic activation and IVF. Theriogenology, 84:226-236.
Kodai T, Umebayashi K, Nakatani T, Ishiyama K, Noda N. 2007. Compositions of royal jelly II. Organic acid glycosides and sterols of the royal jelly of honeybees (Apis mellifera). Chem Pharm Bull (Tokyo), 55:1528-1531.

Kridli R, Husein M, Humphrey W. 2003. Effect of royal jelly and GnRH on the estrus synchronization and pregnancy rate in ewes using intravaginal sponges. Small Rumin Res, 49:25-30.

Kridli R, Al-Khetib S. 2006. Reproductive responses in ewes treated with eCG or increasing doses of royal jelly. Anim Reprod Sci, 92:75-85.

Kwak S-S, Cheong S-A, Jeon Y, Lee E, Choi K-C, Jeung E-B, Hyun S-H. 2012. The effects of resveratrol on porcine oocyte in vitro maturation and subsequent embryonic development after parthenogenetic activation and in vitro fertilization. Theriogenology, 78 86-101.

Leyens G, Knoops B, Donnay I. 2004. Expression of peroxiredoxins in bovine oocytes and embryos produced in vitro. Mol Reprod Dev, 69:243-251.

Lorenzo P, Illera M, Illera J, Illera M. 1994. Enhancement of cumulus expansion and nuclear maturation during bovine oocyte maturation in vitro by the addition of epidermal growth factor and insulin-like growth factor I. J Reprod Fertil, 101:697-701.

Maleki EM, Eimani H, Bigdeli MR, Narenji AG, Abedi R. 2016. Effects of crocin supplementation during in vitro maturation of mouse oocytes on glutathione synthesis and cytoplasmic maturation. Int $J$ Fertil Steril, 10:53-61.

Mishra A, Reddy I, Gupta P, Mondal S. 2016. Lcarnitine mediated reduction in oxidative stress and alteration in transcript level of antioxidant enzymes in sheep embryos produced in vitro. Reprod Domest Anim, 51:311-321.

Mohammadi-Sangcheshmeh A, Soleimani M, Deldar H, Salehi M, Soudi S, Hashemi SM, Schellander K, Hoelker M. 2012. Prediction of oocyte developmental competence in ovine using glucose-6-phosphate dehydrogenase (G6PDH) activity determined at retrieval time. J Assist Reprod Genet, 29:153-158.

Moradi A, Malekinejad H, Farrokhi-Ardabili F, Bernousi I. 2013. Royal Jelly improves the sperm parameters of ram semen during liquid storage and serves as an antioxidant source. Small Rumin Res, 113:346-352.

Mukherjee A, Malik H, Saha AP, Dubey A, Singhal DK, Boateng S, Saugandhika S, Kumar S, De S, Guha SK, Malakar D. 2014. Resveratrol treatment during goat oocytes maturation enhances developmental competence of parthenogenetic and hand-made cloned blastocysts by modulating intracellular glutathione level and embryonic gene expression. J Assist Reprod Genet, 31:229-239.

Nagai T, Inoue R. 2004. Preparation and functional properties of water extract and alkaline extract of royal jelly. Food Chem, 84:181-186.

Oyawoye O, Gadir AA, Garner A, Constantinovici N, Perrett C, Hardiman P. 2003. Antioxidants and reactive oxygen species in follicular fluid of women undergoing IVF: relationship to outcome. Hum Reprod, $18: 2270-2274$ 
Rizos D, Ward F, Duffy P, Boland MP, Lonergan P. 2002. Consequences of bovine oocyte maturation, fertilization or early embryo development in vitro versus in vivo: implications for blastocyst yield and blastocyst quality. Mol Reprod Dev, 61:234-248.

Rodríguez-González E, López-Bejar M, Mertens MJ, Paramio MT. 2003. Effects on in vitro embryo development and intracellular glutathione content of the presence of thiol compounds during maturation of prepubertal goat oocytes. Mol Reprod Dev, 65:446-453.

Romero-Arredondo A, Seidel GE Jr. 1996. Effects of follicular fluid during in vitro maturation of bovine oocytes on in vitro fertilization and early embryonic development. Biol Reprod, 55:1012-1016.

Shahzad Q, Mehmood MU, Khan H, ul Husna A, Qadeer S, Azam A, Naseer Z, Ahmad E, Safdar M, Ahmad M. 2016. Royal jelly supplementation in semen extender enhances post-thaw quality and fertility of Nili-Ravi buffalo bull sperm. Anim Reprod Sci, 167:8388.

Silici S, Ekmekcioglu O, Eraslan G, Demirtas A. 2009. Antioxidative effect of royal jelly in cisplatininduced testes damage. Urology, 74:545-551.

Soto-Heras S, Roura M, Catalá MG, MenéndezBlanco I, Izquierdo D, Fouladi-Nashta AA, Paramio MT. 2018. Beneficial effects of melatonin on in vitro embryo production from juvenile goat oocytes. Reprod Fertil Dev, 30:253-261.

Souza-Fabjan JM, Locatelli Y, Duffard N, Corbin E, Touzé JL, Perreau C, Beckers JF, Freitas VJ, Mermillod P. 2014. In vitro embryo production in goats: slaughterhouse and laparoscopic ovum pick upderived oocytes have different kinetics and requirements regarding maturation media. Theriogenology, 81:10211031.

Souza-Fabjan JMG, Locatelli Y, Duffard N, Corbin E, Batista RITP, de Figueirêdo Freitas VJ, Beckers JF, Mermillod P. 2016. Intrinsic quality of goat oocytes already found denuded at collection for in vitro embryo production. Theriogenology, 86:1989-1998.

Sutton M, Gilchrist R, Thompson J. 2003. Effects of in-vivo and in-vitro environments on the metabolism of the cumulus-oocyte complex and its influence on oocyte developmental capacity. Hum Reprod Update, 9:35-48.

Tamura S, Kono T, Harada C, Yamaguchi K, Moriyama T. 2009. Estimation and characterisation of major royal jelly proteins obtained from the honeybee Apis merifera. Food Chem, 114:1491-1497.

Tarin JJ, Vendrell FJ, Ten J, Blanes R, Van Blerkom J, Cano A. 1996. The oxidizing agent tertiary butyl hydroperoxide induces disturbances in spindle organization, c-meiosis, and aneuploidy in mouse oocytes. Mol Hum Reprod, 2:895-901.

Valiollahpoor Amiri M, Deldar H, Pirsaraei ZA. 2016. Impact of supplementary royal jelly on in vitro maturation of sheep oocytes: genes involved in apoptosis and embryonic development. Syst Biol Reprod Med, 62:31-38.

Van Soom A, Vandaele L, Goossens K, de Kruif A, Peelman L. 2007. Gamete origin in relation to early embryo development. Theriogenology, 68:S131-S137.

Viuda-Martos M, Ruiz-Navajas Y, Fernández-López J, Pérez-Alvarez JA. 2008. Functional properties of honey, propolis, and royal jelly. J Food Sci, 73:117-124. Wrenzycki C, Stinshoff H. 2013. Maturation environment and impact on subsequent developmental competence of bovine oocytes. Reprod Domest Anim, 48:38-43.

Yoneda A, Suzuki K, Mori T, Ueda J, Watanabe T. 2004. Effects of delipidation and oxygen concentration on in vitro development of porcine embryos. $J$ Reprod Dev, 50:287-295.

Zhou Z, Jia RX, Zhang G, Wan Y, Zhang Y, Fan Y, Wang Z, Huang P, Wang F. 2016. Using cysteine/cystine to overcome oxidative stress in goat oocytes and embryos cultured in vitro. Mol Med Rep, 14:1219-1226. 